\title{
INVESTOR SENTIMENT AND SPECULATIVE BOND YIELD SPREADS
}

\author{
Gozde TURKMEN MULDUR*, Serkan Yılmaz KANDIR**, Yıldırım Beyazıt ONAL*** \\ *Science and Technology University, Faculty of Business Administration, Adana, TURKEY \\ e-mail: gturkmen@adanabtu.edu.tr \\ **, ${ }^{* * *}$ Cukurova University, Faculty of Business Administration, Adana, TURKEY \\ **e-mail: skandir@cu.edu.tr \\ ***e-mail: yildirimonal@atu.edu.tr
}

\begin{abstract}
The valuation of risky debt is central to theoretical and empirical work in corporate finance. Although much is known on the returns and valuation of bonds, there is hardly a consensus on the risk components of the yield spreads. This article aims to investigate the effect of investor sentiment as a systematic risk factor on speculative bond yield spreads. After applying correlation analysis to determine the strength of linear association between these two variables, a vector autoregressive (VAR) analysis and impulse response tests are used to examine the relationship between these two variables. The sample period extends from January 1997 to August 2014. In the VAR models, speculative bond spreads and consumer confidence index are used as endogenous variables. The results show that sentiment covaries with the yield spread and have a negative effect on them. The spread level of the previous period seems to be a statistically significant determinant of the current period sentiment. Empirical findings imply that investor sentiment is a systematic risk factor in risky bond markets.
\end{abstract}

Keywords: investor sentiment, speculative bonds, bond spreads, VAR analysis, junk bonds.

JEL: G12, G15, G40.

\section{Introduction}

Bonds would serve as a means of earning a predictable return. Similar to any other financial asset, the value of a bond may be calculated by discounting future cash flows in the form of a coupon and principal payments. The rate when discounting the cash flows to the present date is referred to as "yield." In traditional models, the yield is determined mainly by three factors: interest rate, the risk of default, and the expected loss in the event of default (Liu, Shi, Wang and $\mathrm{Wu}, 2009$ ). Thus premiums are the reason for different debt securities with different market rates. As the yields of bonds differ across different risk groups, there has been extensive development of rating-based models for the empirical modeling of corporate bond prices (Elton, Gruber, Agrawal, and Mann, 2004). But the majority of these models are not sufficient to fully explain the yields of corporate bonds. In the literature, the components of the spread between corporate bond rates and government bond rates are classified into three groups. These are expected default loss, tax premium, and the risk premium (Fons, 1994; Delianedis and Geske, 2001; Huang and Huang, 2003; Sypros, 2013). However, all of the variables that are potential determinants of spread changes have rather limited explanatory power (Elton, Gruber, Agrawal, and Mann, 2001; Collin-Dufresne, Goldstein, and Martin, 2001). Rather than attempting to put forward the determinants of the bond yields, this article aims to explore the systematic effect of investor sentiment on the speculative bond yield spreads.

Traditional finance argues that rational investors lead the financial markets to equilibrium via arbitrage, so security prices would reflect risk-based fundamentals. However, a considerable amount of empirical work shows that security price movements often fall beyond the reasonable explanations based on rational investors and risk-based pricing models. This has led to a rise in interest for behavioral aspects of financial markets (Nayak, 2010). Only since the mid-1980s, there has been a serious attempt to explore the possibility that financial markets are not always as smooth as might be suggested by the efficient market hypothesis (Brown and Cliff, 2004). In his milestone study, Black (1986) posited that some investors trade on a "noisy" signal that is unrelated to fundamentals and that would lead asset prices to deviate from their 
intrinsic values. Likewise, De Long and others (1990) investigated the irrational behavior of individual investors; and Lee and others (1991) found that individual investor sentiment and market prices are associated.

Brown and Cliff (2004) explained sentiment as the representation of the expectations of market participants relative to a norm. So sentiment denotes the level of irrational beliefs in projections of future cash flows and risks underlying any security. When investors fear that the economy will worsen, they become afraid that the market will fall and they will lose money. As a result, they tend to sell their securities that may cause the market to fall. People of the 21st century are bombarded with financial news. With a continuous and uninterrupted source of information, called the Internet, along with the broadcasts from the mass media, these news are directing unsophisticated investors to a certain direction according to their perceptions. Whether investor sentiment has any aspects on asset returns has long been debated.

Several recent articles provided information on the systematic mispricing in the financial markets (Shiller, 1981; Daniel and Titman, 1997; Neal and Wheatley, 1998; Shleifer, 2000; Wang 2006) and evidence of mispricing affecting the asset prices (Otto, 1999; Brown and Cliff, 2004; Baker and Wurgler, 2006; Chung, Hung, Yeh, 2012). The mispricing gets corrected as the economic fundamentals are revealed and sentiment wanes. Therefore, the pricing correction results in a negative relationship between investor sentiment and future returns. As a consequence, investor sentiment exhibits predictive power for returns (Chung, Hung, and Yeh, 2012).

The effect of investor sentiment in equity markets is well documented. But it is still little known about whether investor sentiment is pervasive across segments of financial markets. There are studies reporting evidence about the mutual interaction of bond and stock markets (Fama and French, 1993; Campbell and Ammer, 1993; Kwan, 1996; Norden and Weber, 2009). Along with these studies, others analyzed the role of investor sentiment in the spot and future markets and the volatility spillovers between them (Verma, 2012; Corredor, Ferrer and Santamaria, 2014).
To the best of our knowledge, the role of sentiment in the pricing of corporate bonds still remains unexplored, except the studies of Baker and Wurgler (2012) and Laborda and Olmo (2014). Although past literature revealed that lower-rated bonds demonstrate larger mispricing, it does not appear to be any recent comprehensive research presenting the role of sentiment on speculative bond yield spreads. This article addresses the gap in the literature by examining speculative yield spreads before and after the recent global financial crisis and intends to give insight into the behavioral issues in corporate bond markets. Although Nayak (2010) investigated a similar area, our study indicates difference by using data during the global financial crisis as well as examining a specific type of corporate bonds.

The remainder of this article is organized as follows. Section 2 summarizes the existing literature on the determinants of the yield spreads. Section 3 presents the data, methodology, and the results of the analysis. Finally, Section 4 makes concluding remarks.

\section{Literature review}

The framework for identifying the determinants of credit spread changes depends on the structural models of default. These models generate predictions for what the theoretical determinants of credit spread changes should be and offer a prediction for whether changes in variables such as spot rate, slope of the yield curve, leverage volatility, probability of a jump, or overall business climate should be positively or negatively correlated with changes in credit spreads (Collin-Dufresne, Goldstein and Martin, 2001).

In one of the early studies about the determinants of bond yield spreads, Sloane (1963) studied varying degrees of risk on equal maturity bonds and tried to explain the different yields from three different approaches and found it useful to use the expectation approach. His results showed that the yield is widened more with low-quality bonds and changes in the outstanding volume of bonds, short-term interest rates, and economic conditions have an impact on the spread. 
Fons (1994) offered a bond pricing model by demonstrating the relationship among credit spread, estimated default likelihood, and recovery rate. His study showed that lower-rated issuers tend to have a wider credit spread. Although his model had a lower regression fit, he explained the discrepancies by the assumption he made in his model about the risk neutrality of the investors. Das and Tufano (1996) also suggested a model for pricing creditsensitive debt. By using stochastic spreads and recovery rates, rather than the fixed ones, the model provided greater variability in spreads in line with that observed in practice. The suggested model allowed spreads to vary even when the firm's rating class did not change.

In their groundbreaking study, Elton, Gruber, Agrawal, and Mann (2001) examined the effects of risk premiums over spreads for the first time and showed that risk premiums explain a substantial portion of the difference. They also showed that risk on corporate bonds is systemic rather than diversifiable and risk premiums increase for lower-rated debt. Collin-Dufresne, Goldstein, and Martin (2001) investigated the determinants of credit spread changes and showed that spread changes are driven by local supply/demand shocks. By using principal components analysis, they showed that spread is mostly driven by a single common factor but they were not able to find any set of variables this can explain that factor.

Longstaff, Mithal, and Neis (2005) used the information in credit default swaps to provide evidence about the size of the default and non-default components in corporate spreads. Their results indicated that the default risk accounts for approximately $70 \%$ of the total spread for BBB and BB - rated bonds. They also found out that the non-default component of spreads is strongly related to market-wide or macroeconomic components.

Giesecke, Longstaff, Schaefer, and Strebulaev (2011) studied corporate bond default rates from 1866 to 2008 and reported that credit spreads are roughly twice as large as default losses. They also examined the relationship between changes in credit spreads and changes in default rates and the financial and macroeconomic variables. They found no evidence of a relation between macroeconomic measures and credit spreads. The one important outcome was the negative coefficient for the stock return and positive coefficient for changes in volatility. These are indicating that the spread widens in periods of increased stock market uncertainty.

Besides these studies modeling or identifying the determinants of the yield spreads, there are a limited number of studies investigating the effect of investor sentiment on the corporate bond spreads. Nayak (2010) is one of the first studies in this area. Nayak (2010) examined the impact of investor sentiment on corporate bond yield spreads for a period of 11 years from 1994 through 2004 for 818 publicly listed companies.

Nayak (2010) used the composite investor sentiment index for regression analysis. He formed eight characteristic-based zero-investment portfolios, and six of the eight zero-investment portfolios' excess spreads are found to be higher when the previous sentiment is high. So yield spreads bear strong correlations with the sentiment variable. Then for each portfolio, he conducted full-period time-series regressions of portfolio yield spreads on beginning-ofperiod sentiment, term factor, and default factor. The results showed that the coefficient of sentiment in six portfolios is significant. The analysis also showed that lower-rated bonds demonstrate larger mispricing than higher-rated bonds.

Spyrou (2013) investigated the yield spread determinants for a sample of European markets from 2000 to 2011. Along with the economic fundamentals, investor sentiment, computed by the European Commission is also used in the regression analysis. The findings of the vector autoregressive (VAR) analysis showed that investor sentiment is a statistically significant determinant for the changes in yield spreads, especially during the crisis period of 20072011. Contemporaneous negative sentiment changes were estimated to lead to contemporaneous positive yield spread changes.

Laborda and Olmo (2013) studied the statistical significance of the market sentiment variable to predict the risk premium on the US sovereign bonds. They applied regression analysis and found that market sentiment has a negative effect on the excess returns, suggesting that a positive investor sentiment momentum implies a drop in bond risk premia. 
Along with these studies, Baker and Wurgler (2012) filled the gap on the effect of investor sentiment on government bond pricing. They found that bonds have a closer link with some stocks than with others because they involve cash flows, risk-based required returns, and investor sentiment in common.

In light of this literature, we test the following hypotheses:

1) Investor sentiment and speculative bond spreads are interrelated. During an expanding economy, investors are seeking for risk and do not require a much extra return to induce them to buy very risky securities, but in crisis times, they become risk averse so the spreads expand.

2) Investor sentiment impacts speculative bond spreads. If the sentiment is low, subsequent spreads are high. Therefore, sentiment leads the bond yield spreads.

The expectations are straightforward. Speculative bonds are more sensitive to sentiment. They have larger mispricing and stronger trends in yield spread conditional on sentiment. Therefore, during high sentiment periods, investors are optimistic and they demand speculative high-yield bonds, causing a decrease in their spreads. Alternatively, during low sentiment periods, pessimistic investors prefer safer assets or demand more return for the risky assets so the yields increase as they adjust their expectations.

\section{Data, methodology, and empirical results}

The data used in this study include monthly estimates of the bond yields and the investor sentiment proxy. The data of speculative bond yield spreads is obtained from the Federal Reserve Bank of St. Louis Economic Research database (FRED). For time series of bond yields, FRED uses Bank of America and Merrill Lynch option-adjusted spreads. This data represent an index value that tracks the performance of US dollar denominated below investment grade rated (those rated $\mathrm{BB}$ or below), also referred as speculative corporate debt publically issued in the US domestic market. These spreads are calculated among an index of bonds with greater than 1 year of remaining maturity, a fixed coupon schedule, a minimum amount outstanding of $\$ 100$ million, and a spot treasury curve. As an indicator of investor sentiment, the University of Michigan Consumer Sentiment Index is used in the analysis. This index is published monthly by the University of Michigan and Thomson Reuters, and it is normalized to have a value of 100 . Before empirical analysis, descriptive statistics related to the speculative bond yield spreads (SPREAD) and investor sentiment (SENTIMENT) variables are shown in Table 1 . As it can be seen, the mean value of sentiment is 87.7 projecting an anticipation of overall economic conditions during the 7 years sample period; while the minimum value is 60.8 because of the effects of global financial crisis happened in the second quarter of 2008. Likewise, speculative bond yield spreads are around $5.4 \%$, going up to $10 \%$ in the second half of 2008 , offering more risk premium during the global crisis.

In addition to descriptive statistics, the correlation coefficient between speculative bond yield spreads (SPREAD) and investor sentiment (SENTIMENT) variables is presented in Table 2 to display the strength of linear association between them.

The large negative correlation reveals the opposite relationship between spreads and sentiment. When there is high sentiment, optimistic market participants become risk seekers and demand risky assets such as speculative bonds. This is causing the price to move up and, therefore, returns to go down. But correlation analysis does not necessarily imply the existence of a relationship between these two variables.

Table 1. Descriptive statistics of spread and sentiment (Source: Authors' own research)

\begin{tabular}{|c|r|r|r|r|r|}
\hline Variables & \multicolumn{1}{c|}{ Mean } & \multicolumn{1}{c|}{ Median } & Maximum Value & Minimum Value & Standard Deviation \\
\hline SPREAD & 5.3914 & 5.0200 & 10.8100 & 2.5400 & 2.0307 \\
\hline SENT & 87.8211 & 87.7000 & 112.0000 & 60.8000 & 12.9746 \\
\hline
\end{tabular}


Table 2. Correlation coefficient between spread and sentiment (Source: Authors' own research)

\begin{tabular}{|c|c|}
\hline Correlation & \\
\hline t-Statistic & \\
\hline (Probability) & \\
\hline \multirow{4}{*}{ SPREAD } & SENTIMENT \\
\hline & -0.50755 \\
\hline & -8.536336 \\
\hline & 0.000000 \\
\hline
\end{tabular}

Therefore, to empirically investigate the hypotheses described in the previous section, a VAR approach is used when investor sentiment and spreads are endogenous variables and lags are allowed. Equations (1) and (2) are estimated simultaneously as a VAR system in levels. The variables, speculative bond yield spreads, and consumer sentiment are expressed in natural logarithm.

$$
\begin{aligned}
& \mathrm{LSPR}=\mathrm{C}(1) * \operatorname{LSPR}(-1)+\mathrm{C}(2) * \operatorname{LSPR}(-2) \\
& +\mathrm{C}(3) * \operatorname{LSPR}(-3)+\mathrm{C}(4) * \operatorname{LSPR}(-4)
\end{aligned}
$$
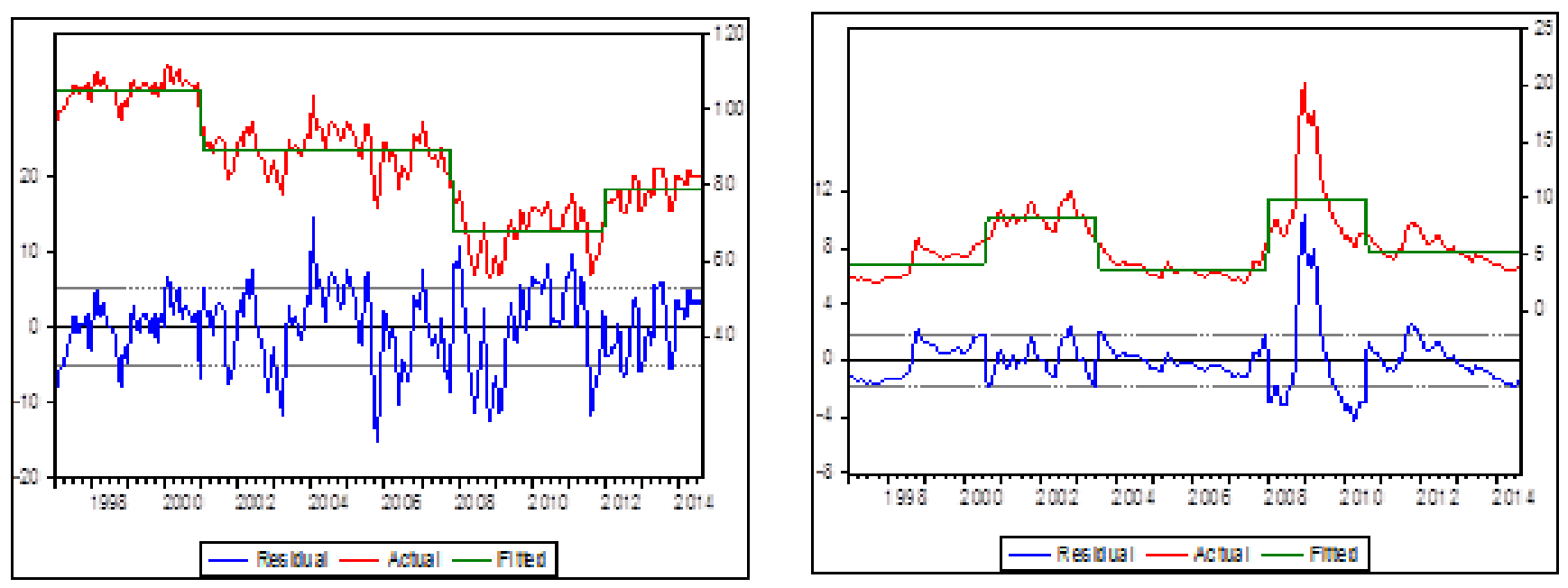

Figure 1. Breakpoints in sentiment and spreads (Source: Authors'own research)

For the analysis, monthly data are collected for a period of 17 years from January 1997 to August 2014. After deleting the major outliers, there are 192 observations. The length of the period is determined by the availability of the two time-series data. The models are estimated in Eviews- 8 software program for the full sample period (1997-2014), and, in order to capture the impact of investor sentiment on the spreads during and after the global financial crisis times, they are re-estimated for a subperiod

$$
\begin{aligned}
& +\mathrm{C}(5) * \operatorname{LSENT}(-1)+\mathrm{C}(6) * \operatorname{LSENT}(-2) \\
& +\mathrm{C}(7) * \operatorname{LSENT}(-3)+\mathrm{C}(8) * \operatorname{LSENT}(-4) \\
& +\mathrm{C}(9)
\end{aligned}
$$

LSENT $=\mathrm{C}(11) * \operatorname{LSPR}(-1)+\mathrm{C}(12) * \operatorname{LSPR}(-2)$

$+\mathrm{C}(13) * \operatorname{LSPR}(-3)+\mathrm{C}(14) * \operatorname{LSPR}(-4)$

$+\mathrm{C}(15) * \operatorname{LSENT}(-1)+\mathrm{C}(16) * \operatorname{LSENT}(-2)$

$+\mathrm{C}(17) * \operatorname{LSENT}(-3)+\mathrm{C}(18) * \operatorname{LSENT}(-4)$

$+\mathrm{C}(19)$ (from December 2007 to August 2014). Fig. 1 presents the breakpoints for both the series. The choice of the subperiod is based on Bai and Perron (1998) breakpoint test. The correct lag length for the system is chosen for the sample period based on both the Akaike and Schwarz information criteria. The augmented Dickey-Fuller (ADF) unit root test reveals that both series are stationary in levels.

The stationary characteristic of the estimated VAR equation is reflected by the inverse roots of the poly- 
nomial lying inside the unit circle, which is the case in this system. The LM autocorrelation test is applied to search for residual serial correlation up to 12 orders and the null hypothesis of no serial correlation of order 12 is failed to be rejected. The results are similar to White's heteroskedasticity test.

Tables 3 and 4 present VAR estimations of the entire sample and the subperiod, respectively. The results in Table 3 indicate that when both spread and local sentiment are treated as endogenous variables and lags are allowed, the previous period spread level is negative and statistically significant at the 5\% level for the determination of current period sentiment level. In addition, the fourth lag of the sentiment level is statistically significant at 5\% level and has a negative sign. These findings are consistent with the expectations. Both the variables are mainly influenced by their own lagged values for up to two periods.

Table 3. VAR Estimations for the period from January 1997 to August 2014

(Source: Authors' own research)

\begin{tabular}{|c|c|c|}
\hline \multicolumn{3}{|c|}{ Included observations: 196; t-statistics in [ ] } \\
\hline & LSPR & LSENT \\
\hline \multirow{2}{*}{$\operatorname{LSPR}(-1)$} & 1.306479 & -0.122039 \\
\hline & {$[17.4093]$} & {$[-2.63172]$} \\
\hline \multirow{2}{*}{$\operatorname{LSPR}(-2)$} & -0.438482 & 0.129345 \\
\hline & {$[-3.61915]$} & {$[1.72769]$} \\
\hline \multirow{2}{*}{$\operatorname{LSPR}(-3)$} & 0.160456 & -0.075612 \\
\hline & [ 1.34391$]$ & {$[-1.02486]$} \\
\hline \multirow{2}{*}{$\operatorname{LSPR}(-4)$} & -0.059035 & 0.047361 \\
\hline & {$[-0.81865]$} & {$[1.06286]$} \\
\hline \multirow{2}{*}{$\operatorname{LSENT}(-1)$} & 0.007197 & 0.787749 \\
\hline & {$[0.05732]$} & [ 10.1533] \\
\hline \multirow{2}{*}{$\operatorname{LSENT}(-2)$} & -0.007252 & -0.067263 \\
\hline & {$[-0.04597]$} & {$[-0.69003]$} \\
\hline \multirow{2}{*}{$\operatorname{LSENT}(-3)$} & -0.228927 & -0.001878 \\
\hline & {$[-1.44750]$} & {$[-0.01922]$} \\
\hline \multirow{2}{*}{$\operatorname{LSENT}(-4)$} & -0.278583 & 0.088532 \\
\hline & {$[2.30578]$} & {$[1.18583]$} \\
\hline \multirow{2}{*}{$\mathrm{C}$} & -0.173628 & 0.932217 \\
\hline & {$[-0.46332]$} & [ 4.02566] \\
\hline Adjusted R-squared & 0.960209 & 0.905547 \\
\hline Sum of squared residuals & 1.041149 & 0.397551 \\
\hline S.E. equation & 0.074817 & 0.046232 \\
\hline F-statistic & 523.8412 & 208.7251 \\
\hline Log likelihood & 235.1914 & 329.5416 \\
\hline
\end{tabular}


Similar findings are obtained from the subperiod analysis during 2007-2014, as well. The current spread is mainly determined by lagged spread, and sentiment is statistically significant for the determination of the yield spread during the period 20072011. An interesting finding demonstrates that sentiment is also affected by spread, implying a feed- back relationship between these two variables. Granger test failed to reject the null hypothesis of "Spread does not Granger Cause Sentiment" at $10 \%$ level but rejected the causality from sentiment to spreads, indicating a weak bi-directional causal relationship between variables.

Table 4. VAR estimations for the financial crisis period form December 2007 to August 2014

(Source: Authors' own research)

\begin{tabular}{|l|c|c|}
\hline \multirow{2}{*}{ Included observations: 69; t-statistics in [ ] } \\
\hline \multirow{2}{*}{ LSPR(-1) } & LSPR & LSENT \\
\hline \multirow{2}{*}{ LSPR(-2) } & 0.926245 & -0.196229 \\
\cline { 2 - 3 } & {$[7.58330]$} & {$[-2.10239]$} \\
\hline \multirow{2}{*}{ LSENT(-1) } & -0.144463 & 0.128449 \\
\cline { 2 - 3 } & {$[-1.44976]$} & {$[1.68688]$} \\
\hline \multirow{2}{*}{ LSENT(-2) } & 0.146467 & 0.595183 \\
\hline \multirow{2}{*}{ C } & {$[0.86067]$} & {$[4.57683]$} \\
\hline Adjusted R-squared & -0.271703 & -0.073485 \\
\hline Sum of squared residuals & {$[-1.81440]$} & {$[-0.64218]$} \\
\hline S.E. equation & 1.265054 & 2.088418 \\
\hline F-statistic & {$[2.26766]$} & {$[4.89896]$} \\
\hline Log likelihood & 0.943183 & 0.680781 \\
\hline \multirow{2yy}{*}{} & 0.243307 & 0.142076 \\
\hline
\end{tabular}

It would be useful to use a structural impulse response analysis because the coefficients may not reveal the magnitude of the dynamic interactions among variables. Fig. 2 presents the structural impulse response functions. The functions in all sample show that speculative bond spreads react negatively to structural innovations in sentiment levels. Following a one-standard deviation shock in the sentiment, spreads drops in the fourth month and maintains its level up to the sixth month. Again in response to spread shocks, sentiment declined in the second month and its decline remained persistent over the plotted horizons. The findings of the subperiod are no different than the findings for the entire sample. For innovations, the response of spread to sentiment goes up in the first month followed by a decline in the second and last among the whole 10 months. 


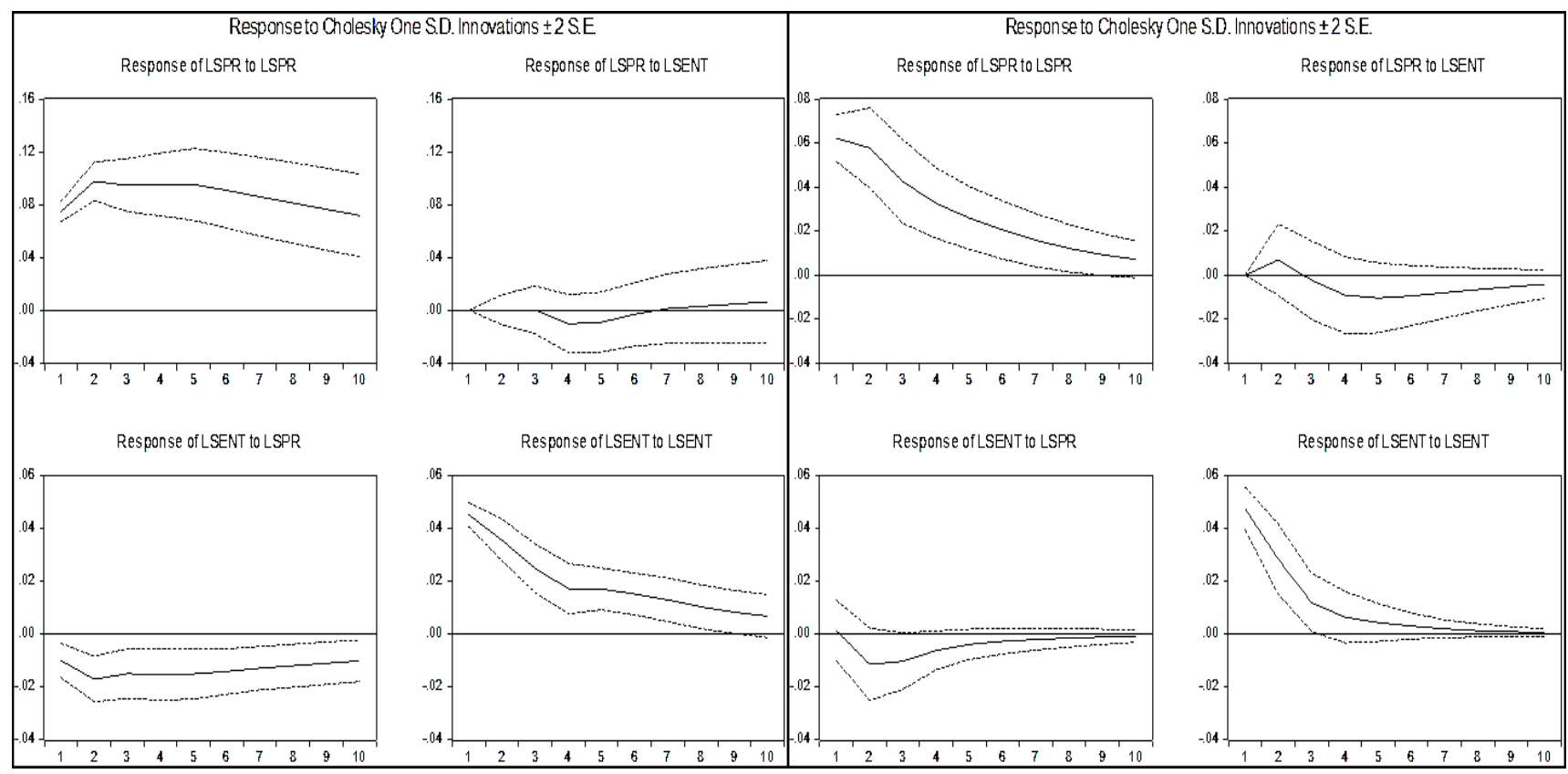

Figure 2. Impulse-response functions of one-standard deviation innovations (Source: Authors' own research)

The findings from this study seem to be in line with those from Nayak (2010), Laborda and Olmo (2013), and Spyrou (2013). In his study, Nayak (2010) found similar patterns in stock markets and posited that in pessimistic periods, bonds become underpriced (with high yields) and overpriced (with low yields) in optimistic periods. Syprou (2013) revealed that third lagged sentiment is a significant variable for the determination of spread and has a negative effect on European markets. Laborda and Olmo (2013) ascertained that market sentiment has a negative effect on the excess returns and those excess returns are more important for periods of high sentiment.

\section{Conclusions}

Empirical studies in behavioral finance maintain that investors may form stochastic beliefs, with either excessive optimism or excessive pessimism, causing asset prices to deviate from their intrinsic values. These studies suggest that it is natural to expect that investor sentiment may well have an impact on the financial markets. The systematic effect of investor sentiment has been very well investigated especially in stock markets. Nevertheless, because of complexity and sophistication of the financial markets, attention has been shifted toward bonds and derivatives markets. Although there are two studies revealing the role of investor sentiment in pricing corporate bonds (Nayak, 2010; Laborda and Olmo, 2013), there is a lack of empirical evidence about speculative bond yield spreads. Using 196 monthly observations, between January 1997 and August 2014, this study aims to answer these questions using a correlation and VAR analysis.

Correlation analysis implies that an increase in sentiment would narrow the spreads down. The result is rather perceptive. High investor sentiment periods are associated with lowering investor risk aversion and a higher desire to borrow against the future. Investors overdemand the speculative bonds, overlook the uncertainty, and eventually drive the value up. Conversely, during the low sentiment periods, they become highly risk averse and simply seek for more compensation for the risk they are bearing above actuarially neutral yields. VAR analysis showed that investor sentiment (fourth lagged) is a statistically significant determinant and it has a negative effect on yield spreads.

However, during and after the global crisis, time lag has shortened to 2 months, revealing the quicker response of the financial market participants. One of the reasons for this difference in timing would be the exposure to more financial news about the scale 
and the direction of the crisis in the mass media. An interesting finding of the study is the effect of spread on investor sentiment as well. Spreads of the previous 2 months seem to impact sentiment level of the current period indicating a bidirectional relation between sentiment and spreads. This implies that rising spread would be the signal for rising interest rates and a shrinking economy, which would affect investors' sense of the future, causing them to lower their expectations and a decrease in the sentiment level.

All-in-all investor sentiment reflects market expectations on future interest rate dynamics and monetary policies as well. This might also be a useful indicator because sentiment has an impact on most of the asset prices. Owing to this feedback effect that is seen in the VAR analysis, a causality relationship has been investigated. A weak causality has been found from spreads to investor sentiment, supporting the opinion on the interest rate movements from the view of the investors.

The findings reveal that investor sentiment effect cannot be restricted with stock markets. Furthermore, similar sentiment effect prevails among bond markets as well. In both the markets, risk levels of securities seem to influence the level of exposure to investor sentiment. In the stock market, sentiment plays an important role in the pricing of shares of small firms. Shares of small firms tend to be riskier than big firms' shares. Likewise, low-quality bonds (assumed riskier) seem to be impacted by investor sentiment.

Finally, as varying spreads may be leading indicators for future interest rates, an indirect relationship between spreads and future stock returns may be suggested. Investor sentiment appears to have the potential for constructing this channel between spreads and expected stock returns. Future studies would investigate the relationship between investor sentiment and bond yield spreads for other national bond markets.

\section{$5 \quad$ References}

[1] Bai, J. and Perron, P., 1998. Estimating and Testing Linear Models with Multiple Structural Changes. Econometrica, pp.47-78.
[2] Baker, M. and Wurgler, J., 2006. Investor Sentiment and the Cross-Section of Stock Returns. The Journal of Finance, 61(4), pp.1645-1680.

[3] Baker, M. and Wurgler, J., 2012. Comovement and Predictability Relationships Between Bonds and the Cross-Section of Stocks. The Review of Asset Pricing Studies, 2(1), pp.57-87.

[4] Black, F., 1976. Studies in Stock Price Volatility Changes. Proceedings of the American Statistical Association, Business and Economic Statistics Section, pp.177-181. 1986. Noise, Journal of Finance, 41, pp.529-543.

[5] Black, F. and Scholes, M., 1973. The Pricing of Options and Corporate Liabilities. Journal of Political Economy, 81(3), pp.637-654.

[6] Brown, G.W. and Cliff, M.T., 2004. Investor Sentiment and the Near-Term Stock Market. Journal of Empirical Finance, 11(1), pp.1-27.

[7] Campbell, J.Y. and Ammer, J., 1993. What Moves the Stock and Bond Markets? A Variance Decomposition for Long-Term Asset Returns. The Journal of Finance, 48(1), pp.3-37.

[8] Charoenrook, A., 2005. Does Sentiment matter. Unpublished working paper. Vanderbilt University.

[9] Chung, S.L., Hung, C.H. and Yeh, C.Y., 2012. When Does Investor Sentiment Predict Stock Returns? Journal of Empirical Finance, 19(2), pp.217-240.

[10] Collin-Dufresn, P., Goldstein, R.S. and Martin, J.S., 2001. The Determinants of Credit Spread Changes. The Journal of Finance, 56(6), pp.2177-2207.

[11] Corredor, P., Ferrer, E. and Santamaria, R., 2015. Sentiment-prone Investors and Volatility Dynamics between Spot and Futures Markets. International Review of Economics \& Finance, 35, pp.180-196.

[12] Daniel, K. and Titman, S., 1997. Evidence on the Characteristics of Cross Sectional Variation in Stock Returns. The Journal of Finance, 52(1), pp.1-33.

[13] Das, S.R. and Tufano, P., 1995. Pricing Credit Sensitive Debt when Interest Rates, Credit Ratings and Credit Spreads Are Stochastic. Journal of Financial Engineering, 5, pp.161-198.

[14] De Long, J.B., Shleifer, A., Summers, L.H. and Waldmann, R.J., 1990. Noise Trader Risk in Fi- 
nancial Markets. Journal of Political Economy, 98(4), pp.703-738.

[15] Delianedis, G. and Geske, R., 2001. The Components of Corporate Credit Spreads: Default, Recovery, Tax, Jumps, Liquidity, and Market Factors. DOI:10.2139/ssrn.306479.

[16] Elton, E.J., Gruber, M.J., Agrawal, D. and Mann, C., 2001. Explaining the Rate Spread on corporate Bonds. The Journal of Finance, 56(1), pp.247-277.

[17] Elton, E.J., Gruber, M.J., Agrawal, D. and Mann, C., 2011. Factors Affecting the Valuation of Corporate Bonds. In: Investments And Portfolio Performance, pp.53-73.

[18] Fama, E.F. and French, K.R., 1993. Common Risk Factors in the Returns on Stocks and Bonds. Journal of Financial Economics, 33(1), pp.3-56.

[19] Fons, J.S., 1994. Using Default Rates to Model the Term Structure of Credit Risk. Financial Analysts Journal, 50(5), pp.25-32.

[20] Giesecke, K., Longstaff, F.A., Schaefer, S. and Strebulaev, I., 2011. Corporate Bond Default Risk: A 150-year Perspective. Journal of Financial Economics, 102(2), pp.233-250.

[21] Huang, J.Z. and Huang, M., 2012. How Much of the Corporate-Treasury Yield Spread is Due to Credit Risk? The Review of Asset Pricing Studies, 2(2), pp.153-202.

[22] Kwan, S.H., 1996. Firm-specific Information and the Correlation between Individual Stocks and bonds. Journal of Financial Economics, 40(1), pp.63-80.

[23] Laborda, R. and Olmo, J., 2014. Investor Sentiment and Bond Risk Premia. Journal of Financial Markets, 18, pp.206-233.

[24] Lee, C.M., Shleifer, A. and Thaler, R.H., 1991. Investor Sentiment and the Closed-end Fund Puzzle. The Journal of Finance, 46(1), pp.75109.

[25] Liu, S., Shi, J., Wang, J. and Wu, C., 2009. The Determinants of Corporate Bond Yields. The Quarterly Review of Economics and Finance, 49(1), pp.85-109.

[26] Longstaff, F.A., Mithal, S. and Neis, E., 2005. Corporate Yield Spreads: Default Risk or Li- quidity? New Evidence from the Credit Default Swap Market. The Journal of Finance, 60(5), pp.2213-2253.

[27] Merton, R.C., 1974. On the Pricing of Corporate Debt: The Risk Structure of Interest Rates. The Journal of Finance, 29(2), pp.449-470.

[28] Nayak, S., 2010. Investor Sentiment and Corporate Bond Yield Spreads. Review of Behavioural Finance, 2(2), pp.59-80.

[29] Neal, R. and Wheatley, S.M., 1998. Do Measures of Investor Sentiment Predict Returns? Journal of Financial and Quantitative Analysis, 33(4), pp.523-547.

[30] Norden, L. and Weber, M., 2009. The coMovement of Credit Default Swap, Bond and Stock Markets: An Empirical Analysis. European Financial Management, 15(3), pp.529-562.

[31] Otoo, M.W., 1999. Consumer Sentiment and the Stock Market. Board of Governors of the Federal Reserve System. November 1999. http://www.federalreserve.gov/pubs/feds/1999/1 99960/199960pap.pdf

[32] Shleifer, A., 2000. Inefficient Markets: An Introduction to Behavioural Finance. OUP Oxford.

[33] Shiller, R.J., 1981. Do Stock Prices Move Too Much To Be Justified By Subsequent Changes In Dividends? American Economic Review. Vol. 71, pp.421-436.

[34] SIFMA. Securities Industry and Financial Markets Association. US Bond Market Issuance and Outstanding, 2014. http://www.sifma.org/ research/statistics.aspx (03.17.2015).

[35] Sloane, P.E., 1963. Determinants of Bond Yield Differentials. Yale Economic Essays, 3(1), pp.355.

[36] Spyrou, S., 2013. Investor Sentiment and Yield Spread Determinants: Evidence from European Markets. Journal of Economic Studies, 40(6), pp.739-762.

[37] Verma, R., 2012. Behavioral Finance and Pricing of Derivatives: Implications for Dodd-Frank Act. Review of Futures Markets, 20, pp.21-67.

[38] Wang, Y.H., Keswani, A. and Taylor, S.J., 2006. The Relationships between Sentiment, Returns and Volatility. International Journal of Forecasting, 22(1), pp.109-123. 